\title{
EXTENSION: TO SERVE AND PROTECT - HOW TO ACHIEVE SUSTAINABLE RURAL DEVELOPMENT
}

\author{
Gillespie, W. A. ${ }^{1}$ and Mitchell, F. J. ${ }^{2}$
}

Correspondence author: W.A. Gillespie. Email: william.gillespie@ sugar.org.za

\begin{abstract}
The dearth of success stories around extension projects implemented across South Africa (and Sub-Saharan Africa), even after substantial investment and effort, begs the question: more extension, less adoption, why? What is the role of extension in contributing to rural upliftment, the development of successful farmers, supporting stable protected natural environments and facilitating sustainable economic returns from agriculture? This paper examines the before and after effects of coordinated extension with clear targets, activities and skills development that is aimed at achieving significant rural development for a KwaZulu-Natal community. The purpose is to compare a period of 10 years of uncoordinated extension services with the following 10 years using a targeted structured extension methodology with set measurable outputs, implemented in the same community. Ten years of data in a community which received uncoordinated extension with little support from outside organisations were compared to the results of the following ten years after the implementation of a new, structured extension approach. Extension officers were upskilled, monitored and evaluated on their impact on the development of agriculture and the improvement of livelihoods in the community. There were 224 growers delivering 16456 tons of sugarcane in 2004. The growth in the agricultural sector over the past decade was compared to the previous ten years and comparisons made for a number of variables which were indicative of the success of the project in terms of adoption, increased agricultural participation and improved production systems. In 2018, there were 704 growers delivering 50300 tons of sugarcane. The rate and scale of adoption, and increased community confidence in agriculture as a livelihood, is clearly evident in the increased number of growers from 419 in 2013 to 704 in 2018. An extension impact monitoring system and annual work plan was also developed to assist extension officers and their managers to have a clear understanding of roles and responsibilities, as well as being utilised to measure the impact of the extension officers in the area. The agricultural system has become a self-perpetuating one that demonstrates the enormous social, developmental and economic benefits of a sustainable agricultural community.
\end{abstract}

Keywords: Adoption, Extension effectiveness, Self-perpetuating, Successful

\section{INTRODUCTION}

The development of appropriate technology and its transfer to farmers are two of the essential enabling conditions to ensure increased agricultural productivity and thus rural development. The complex nature of rural communities, land ownership, socio-economic issues and access to natural resources make it imperative that more effective investment in farmer-centred

\footnotetext{
${ }^{1}$ Extension Specialist, South African Sugarcane Research Institute, Mount Edgecombe, South Africa. Email: william.gillespie@sugar.org.za

2 Scientific Manager: Natural Resources, KZN Department of Agriculture and Rural Development, Pietermaritzburg, South Africa. Email: felicity.mitchell@kzndard.gov.za
} 
agricultural research, supported by skilled extension, is needed which is innovative, appropriate and relevant to localised needs and conditions and assists with finding solutions to emerging agricultural problems within rural communities. The dearth of success stories around extension projects implemented across South Africa (and Sub-Saharan Africa), even after substantial investment and effort, begs the question: more extension, less adoption, why? What is the role of extension in contributing to rural upliftment, the development of successful farmers, supporting stable protected natural environments, and facilitating sustainable economic returns from agriculture? Continued investment into small-scale, communally-based agricultural projects has been shown to be unsustainable and very few projects have led to viable outcomes and sustainable resource utilisation or directly contributed to job creation or sustained income generation (van Niekerk et al, 2009; van Rooyen \& Bembridge, 1998).

With specific reference to the South African sugar industry, small sugarcane growers, contribute well below that of modelled yield potential for comparative areas (Cockburn et al, 2014). Small growers require an innovative yet practical extension approach since their needs differ from those of commercial growers, particularly in terms of access to finance, information, equipment, weedicides, agronomic knowledge, and production practices. It is paramount that communities identify with the proposed technology and feel safe (in terms of risk to self) when adopting it. So how can extensionists prove this other than by implementing the Demonstration Plot Extension Methodology (DPEM) (Gillespie et al, 2009; Gillespie et al, 2012; Gillespie \& Mitchell, 2006; Gillespie \& Mitchell, 2014), where the project is implemented with the full consent and commitment from the farmers and on their own land? This successful approach has upskilled local extension officers and has been fully adopted by the communities involved, leading to a self-sustaining production system. Therefore, this paper explores the outputs from a community for a decade before the introduction of the DPEM with results for ten years after the introduction of DPEM.

\section{PURPOSE AND BACKGROUND}

While researchers around the world continue to develop solutions to assist in smallholder development, there is also a need to make regional technology adoption and transfer more costeffective and efficient. The link between research results and the farmer is extension, a complex position which requires communication, scientific, analytical and assessment skills, and an understanding of local social psychology within a community to be able to transfer complex information from research institutes to those who require it on the ground. Extension organisations in developing rural areas need to have clear deliverables and structures, management of both the projects, as well as the activities of the extension personnel so as to increase their effectiveness, capability and service delivery to farmers. When farmers are involved in developing and innovating technologies, they take ownership for success. These technologies must be within the skills and ability of the growers and have continued support until they become sustainable, even if it means some initial subsidy by government.

The purpose of this study was to:

1. Evaluate the effectiveness of DPEM as a project implementation system over a 20 year period (a decade before implementation and a decade after implementation), and

2. Evaluate the effectiveness of the implementing extension officers over the last 20 years of the project. 
DPEM is a rigorous and systematic approach to implementation of a project (regardless of enterprise) by following the steps below (Gillespie \& Mitchell, 2014):

1. Consultation and buy-in from all role-players.

2. Obtain finance for the project.

3. Selection of a co-operator for the demonstration plot on a suitable site.

4. Establish a programme of work for the growers and extension staff (for technology transfer to the community) following the agronomic cycle of the chosen enterprise.

5. Land assessment and soil classification must be undertaken and then linked to economic viability.

6. Secure suitable seedcane (correct variety, pest and disease-free via the Pest and Disease and Variety Control Committee (P\&D\&VCC) and confirm availability and price).

7. Technology transfer at a soil conservation practical planning day.

8. Technology transfer at a soil fertility practical information day.

9. Land preparation planning and training day (might include lime application if needed).

10. Planting field day and practical.

11. Weedicide planning and practical training day.

12. Topdressing field day and practical training day.

13. Variety and pest and disease practical training day.

14. Estimating field day and harvesting practical training days.

15. Cane payment (seedcane or mill) and role-players field days.

By incorporating the technical training as a practical process during the implementation of the project, this enables both the growers and the extension officers to learn and reinforce the skills and agronomic steps that will be necessary annually to ensure a good crop. In many instances, extension officers may know the theory, but have never farmed or, for example, calibrated a knapsack or calculated herbicide concentrations for a given area, and thus do not know how to demonstrate these skills in the field. Extension officers also need to have credibility with the growers, and therefore must be able to demonstrate and encourage growers to use good agricultural practices. This starts by being able to do it themselves. With the new entrant extension officers, there is often a gap between theory and practical skills and a lack of experienced mentors is a distinct failure in existing extension development programmes.

Another difficulty for extension managers is monitoring extension performance, namely how to measure their effectiveness in the field. Current personnel evaluation systems tend to consider inputs, for example, budget spent, number of projects implemented, and hectares planted, but seldom measure performance on achieved targets such as number of farmers trained, tons of food produced, income received by a household, and improved livelihoods (e.g. ability to purchase sufficient nutritious food, pay school fees, build a bigger house). The management of extension officers must be re-evaluated in order to improve their effectiveness and efficiency, particularly since the objective of extension is to be accountable for funds spent, provide relevant information and advisory services and training for clients which lead to profitability, productivity and sustainability linked to research innovations, in other words, be results-oriented (Alex, Zijp \& Byerlee, 2002).

Over the past 20 years, the Noodsberg small-scale grower sugarcane mill supply community have had continuous extension involvement, but prior to the implementation of the DPEM (1999 to 2008) they were unaware of their soil potential, variety choice, seedcane availability and training in the skills required to manage a crop. There were also social issues such as crop destruction by cattle, incorrect sugarcane burning times, and sugarcane was not seen to be a 
profitable crop due to the high start-up costs for planting sugarcane (access to finance). The various areas that make up the study area community have similar natural resources in that all eight communities assessed have humic soil forms with depths not shallower than $630 \mathrm{~mm}$, mainly of the Sweetwater, Nomanci, Magwa, Inanda and Kranskop soil forms. The sites fall along the same topographical area on an upland mistbelt crest. The long term mean annual rainfall is $825 \mathrm{~mm}$ and the median is $743 \mathrm{~mm}$. All sugarcane is produced under dryland conditions over a 24 month cycle. Mean monthly maximum temperatures peak at $25^{\circ} \mathrm{C}$ in February, while the mean monthly minimum drops to $6.4^{\circ} \mathrm{C}$. Frost incidence is very low and not severe. No significant differences exist between the various sites in terms of road networks and all sites fall within $50 \mathrm{~km}$ of the mill. All farming systems in the area are based on communal tenure. The DPEM plots (from 2008) are mostly two hectares and contain at least two varieties to allow for comparison between varieties. Growers rely almost entirely on contactors to supply equipment and services.

Prior to 2008, extension services were uncoordinated and there was no distinct plan on how to progress the farmers, thus most projects failed. Once the systematic DPEM methodology was developed and implemented in this area (from 2009 onwards), adoption of technologies, yields, area, access to seedcane, and grower and extension competence improved. Included in the methodology are defined training days which reinforce the extension personnel and growers' practical knowledge since practical demonstrations in the field are made alongside and including the farmers.

\section{METHODOLOGY}

From 1999 to 2008, the area under cane and tons of sugarcane delivered to the mill were assessed for a number of specified sites and compared to the same factors for the decade from 2009 to 2018. This was all accessed from mill records, in other words, these are documented and verified. Comparison was made between the outputs from the decade before implementation with those after DPEM. The figures are represented graphically for ease of reference. All eight communities that made up the mill supply area were added together to give the totals for each parameter used to indicate successful implementation and adoption. Thus, the results are indicative of all areas that supply the Noodsberg Mill. The two main parameters used were tons of sugarcane delivered (yield) and income as indicators of adoption of sugarcane as a crop with its concurrent agronomic technological responsibilities and activities, as a means of achieving better livelihoods. These were the end results of the adoption of all the steps implemented during the setting up of a demonstration plot, including changing to new varieties, using better land preparation techniques, taking soil fertility samples for more accurate fertilizer choice and application, the correct selection and application of weedicides, and better soil conservation practices.

\section{RESULTS AND DISCUSSION}

\subsection{9-2008: Before DPEM implementation}

The number of growers and area under cane from 1999 to 2008 were taken to be indicative of the lack of coordinated extension and very little targeted training around the agronomic cycle of sugarcane production. In addition, no soil classification had been undertaken to assess the land potential of the area as a whole nor had new variety choices been readily offered or made available to these communities. Extension input was haphazard with no clear or defined inputs 
and role-players were not well coordinated. The graph showing yield (tons delivered) prior to DPEM being implemented (Figure 1) indicates an average of 20531 tons was delivered per annum over the 10 year period, with an average yield per season of 61 tons/hectare (t/ha).

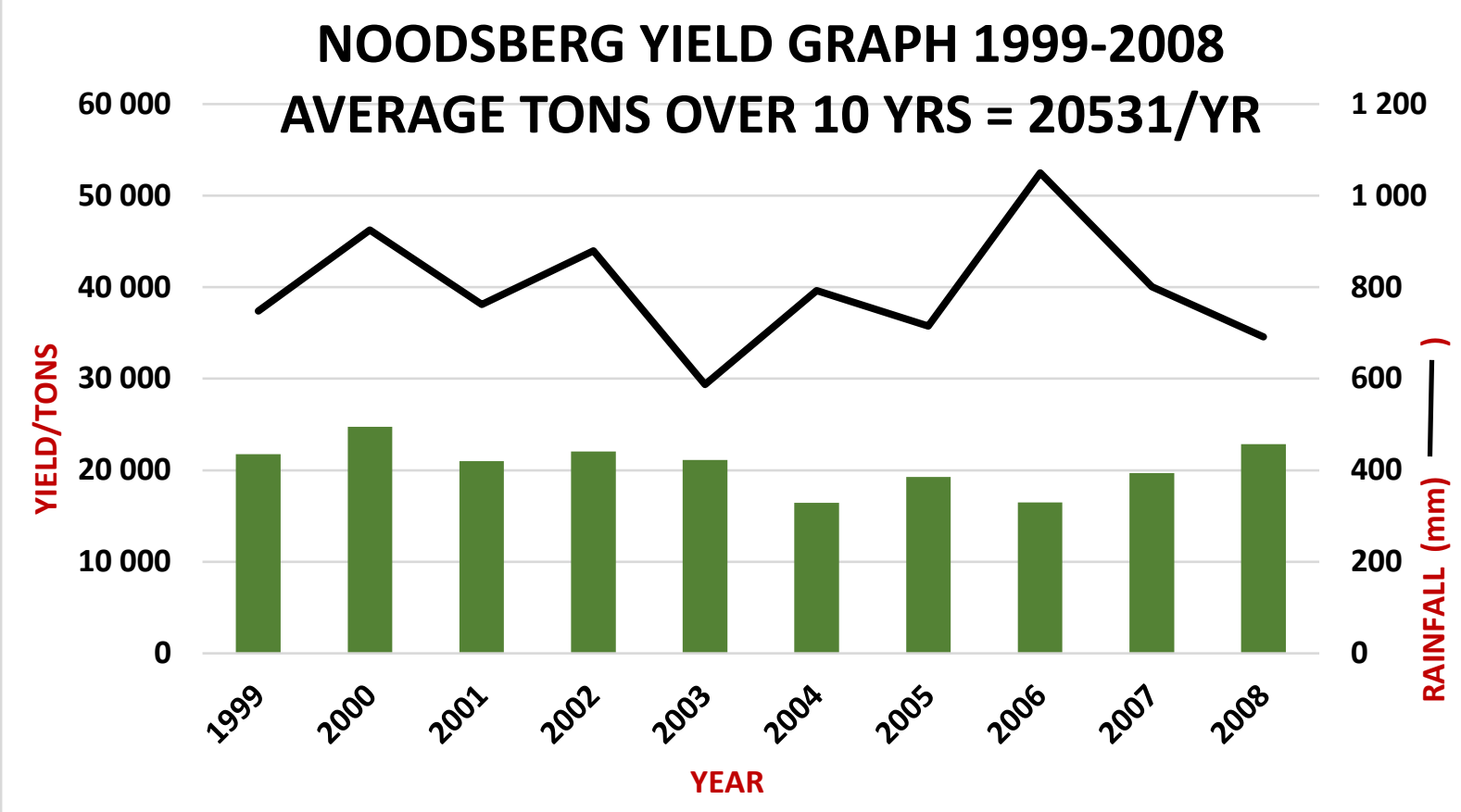

Figure 1: Sugarcane yield (tons) delivered to the mill from the study area between 1999 and 2008

\subsection{9-2018: After DPEM implementation}

After the implementation of the DPEM methodology in 2009 to 2018, improved yields from new varieties indicated widespread adoption of new technologies such as the introduction of soil classification for new variety choices, soil sampling, fertility management, weedicides, pest and disease control, and inspections. The two figures clearly show that while rainfall fluctuated from season to season, the variation across the 20 year period was not significant enough to account for the increase in production. The average yields improved from $61 \mathrm{t} / \mathrm{ha}$ before DPEM to $74 \mathrm{t} / \mathrm{ha}$ after DPEM, an increase of $21 \%$, while the average tons of sugarcane delivered to the mill per year increased from 20531 tons per year to 35574 tons per year, an increase of $73 \%$ (continuous growth in area planted).

Increased yields post-DPEM (Figure 2) have had a significant and concurrent increase in household income. At today's price per Recoverable Value (RV) of R3808.72 and $12.34 \%$ RV, this represents an increase of R5798.00 per hectare due to the adoption of DPEM. Between 1999 and 2008, an average of 343 hectares were harvested per annum and a total of R98.33 million was generated for the community from sugarcane production during this period. Between 2009 and 2018, an average of 514 hectares were harvested per annum, generating a total income of R178.76 million for these communities during this period. The value of DPEM to this community is thus R80.39 million additional revenue over the past 10 years and can be attributed to the correct selection of soil type, new varieties, better agronomic practices, and improved business skills. The extension officers have also been upskilled to the point that they are able to undertake the training with confidence and demonstrate the practical skills required with each new grower group. 


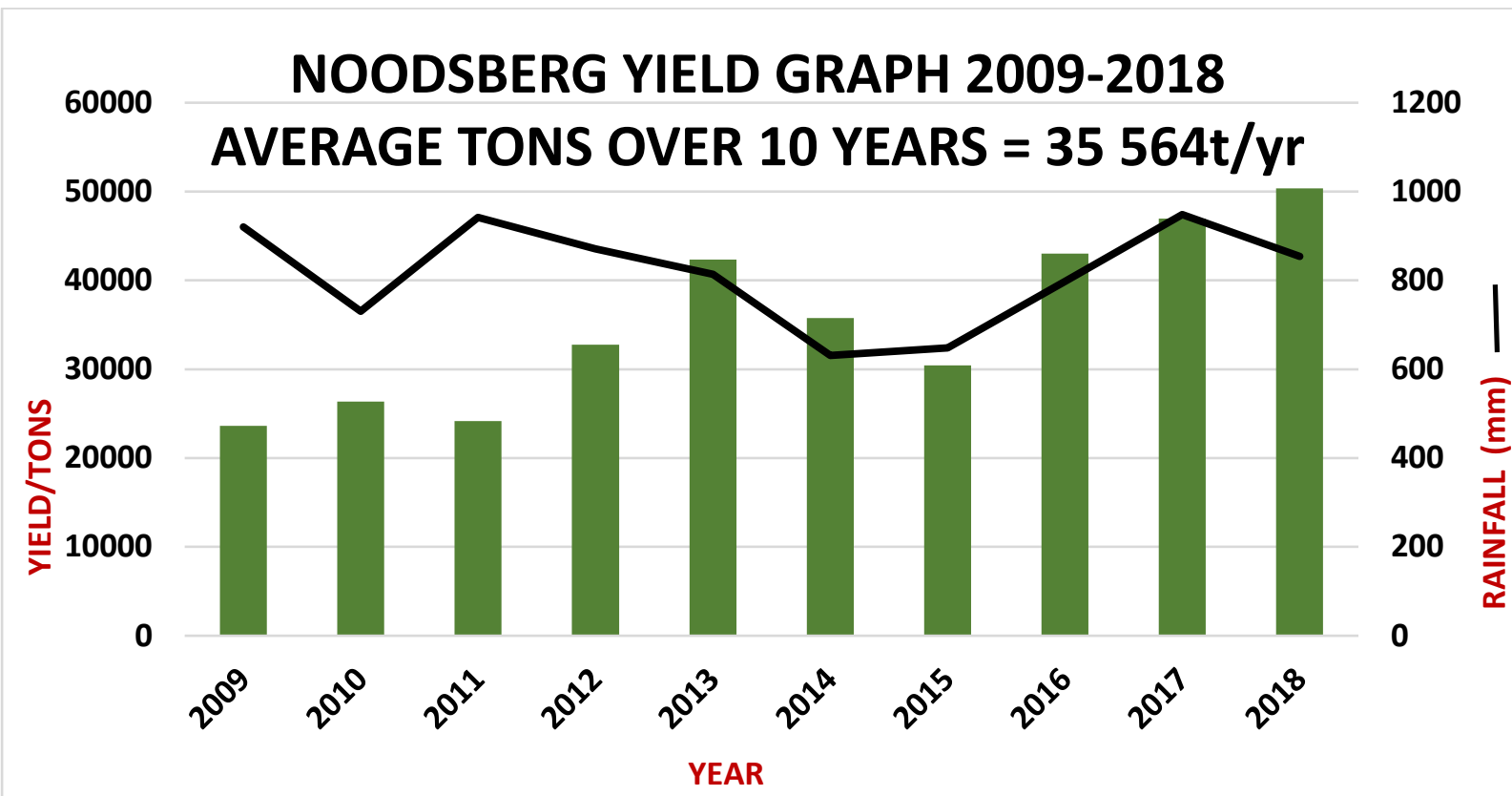

Figure 2: Sugarcane yield (tons) delivered to the mill from the study area between 2009 and 2018

\subsection{Effectiveness of extension using DPEM in the study area}

The figures above are representative of communities that have been given the opportunity to improve the way in which they were undertaking their agricultural activities through a rigorous, systematic information and training system. There was a concurrent improvement in the skill set of the extension officers involved, which will continue as they provide mentorship to new employees and farmers. The increased area under sugarcane after 2008 is representative of the technology transfer events, creating awareness about sugarcane as a viable cropping option as well as the extensionists' ability to create linkages between role-players. The adoption of sugarcane as the main economic crop is indicative of the level of awareness created through extension, as well as recognition of the link between scientific research, land potential, yield, income and economic opportunity.

Yields achieved in the study area were directly comparable to the adjacent commercial growers due to adoption of good agricultural practices such as pest and disease control, soil sampling, use of appropriate weedicides and fertilizers, choosing suitable varieties, harvesting times, contour planting for erosion control, and reducing the time between cane cutting and delivery to the mill. Variety selection and pest and disease inspections were identified as two of the largest knowledge gaps which the DPEM addressed. These results indicate the enormous opportunity cost of ineffective extension (when the methodology now exists to correct this) for the rural communities who depend on extension staff as their source of support, technology transfer and link to research results, role-players and access to financial support. 


\subsection{Monitoring and evaluation of extensionists}

There is significant responsibility on extension staff to have a clear understanding of their job description, key performance targets and be evaluated fairly as well as monitored by their managers. Managers should also be aware of under skilled (and thus underperforming) officials, identify these gaps and provide training and mentorship before their actions negatively impact the communities in which they work (Gillespie \& Mitchell, 2015). Table 1 shows an annual programme of work as laid out monthly to assist the extension officer with measurable tasks and goals to be monitored and evaluated for performance assessment.

By assessing the extension level of contact with growers and interventions, the area is now receiving training and support with an annualised programme of work (work plan) showing monthly activities and technology transfer events. This study has allowed for the significant improvements in terms of job creation, stability, income, and the growth of an agricultural industry within the community to be quantified as well as the role that an effective extension methodology can play in changing the lives of communities. Extension targets are clear, monthly reports are used as a monitoring tool, and the yields are an indication (other than extreme or unpredictable events, runaway fires, etc.) of whether his/ her work has been effective.

This methodology has created change and spurred development in the area, most notably the following: all role-players are fully committed to the programme, finance for the project is no longer an issue since the mill and the farmers are benefitting financially, and more demonstration plots (which are local seedcane nurseries for the first two crops) are put in place each year to provide a continuous supply of cheaper locally-produced seedcane which is both cheaper and pest and disease-free. A detailed programme of work is followed by the extension personnel and the farmers. All plots have been assessed in terms of slope and soil type and varieties matched to the soils present, soil conservation practices have improved, soil samples submitted for fertility analysis have increased fivefold since DPEM. Planting is done using good agricultural practices and weedicide and topdressing applications are more accurately applied. These are all indicators that both the farmers and the extension support staff have been upskilled and that the DPEM methodology is in fact effective.

\section{CONCLUSION}

DPEM has been proven to be an effective project implementation system which can be applied to other commodities and in other areas. A decade (1999-2008) where extension efforts were uncoordinated and sugarcane was not seen as a viable enterprise from which to make a living, has cost the communities involved many millions in revenue during that decade. After implementation, the following decade saw massive growth in both area and yields of sugarcane, and spurred social, economic and agricultural development in the area. To avoid the failure of development projects, this type of methodology should become the protocol adopted to ensure new technologies are adopted and extension effectiveness is rigorously evaluated and quantified. The results of this study confirm that the DPEM approach provides a robust model to achieve increased production and extension effectiveness in small-scale grower regions of South Africa. 
S. Afr. J. Agric. Ext.

Vol. 47 No. 4, 2019: 9 - 17

http://dx.doi.org/10.17159/2413-3221/2019/v47n4a522

Table 1: Example of a Programme of work for an Extension officer to implement DPEM

Training and Mentorship Programme (Grading scores: Agenda 2 points; Attendance 3 points; Report 5 points; 12 field days x $10=120$ points)

\begin{tabular}{|c|c|c|c|c|c|c|c|c|c|c|c|c|}
\hline \multicolumn{5}{|c|}{ Agricultural Advisor: } & \multicolumn{8}{|c|}{ Name of demonstration plot: } \\
\hline & $\begin{array}{l}\text { Name of } \\
\text { Co- } \\
\text { operator }\end{array}$ & $\begin{array}{l}\text { Co-operator's } \\
\text { Cell Number }\end{array}$ & Municipality & $\begin{array}{l}\text { Local } \\
\text { Area } \\
\text { Manager }\end{array}$ & $\begin{array}{l}\text { Area } \\
\text { Manager's } \\
\text { Cell } \\
\text { Number }\end{array}$ & $\begin{array}{l}\text { Local Mill } \\
\text { Contact: }\end{array}$ & $\begin{array}{l}\text { P\&D Officer } \\
\text { Contact }\end{array}$ & $\begin{array}{l}\text { Demonstration } \\
\text { plot soil type }\end{array}$ & $\begin{array}{l}\text { GPS Co- } \\
\text { ordinates } \\
\text { South }\end{array}$ & $\begin{array}{l}\text { GPS Co- } \\
\text { ordinates East }\end{array}$ & $\begin{array}{l}\text { Varieties to be } \\
\text { planted }\end{array}$ & $\begin{array}{l}\text { Seedcane } \\
\text { obtained } \\
\text { from }\end{array}$ \\
\hline & January & February & March & April & May & $\begin{array}{l}\text { June } \\
\text { *start here* }\end{array}$ & July & August & September & October & November & December \\
\hline PLANT & & $\begin{array}{l}\text { Activity: } \\
\text { Project } \\
\text { proposal/ } \\
\text { business plan } \\
\text { submitted. } \\
\text { Establish } \\
\text { dates for } \\
\text { training days. }\end{array}$ & $\begin{array}{l}\text { Activity: } \\
\text { Establish } \\
\text { seedcane } \\
\text { requirements } \\
\text { and payment } \\
\text { with role } \\
\text { players. }\end{array}$ & & $\begin{array}{l}\text { Activity: } \\
\text { Demo } \\
\text { Plot site } \\
\text { selection }\end{array}$ & $\begin{array}{l}\text { 1) Soil } \\
\text { potential\& } \\
\text { business } \\
\text { skills } \\
\text { training day } \\
\text { Date: }\end{array}$ & $\begin{array}{l}\text { Activity: } \\
\text { Confirm } \\
\text { seedcane } \\
\text { with P \& D } \\
\text { \& VCC } \\
\text { officer }\end{array}$ & $\begin{array}{l}\text { Activity: } \\
\text { Volunteer } \\
\text { removal } \\
\text { Activity: Fencing } \\
\text { 2) Soil } \\
\text { conservation \& } \\
\text { farm planning } \\
\text { training day } \\
\text { Date: } 27\end{array}$ & $\begin{array}{l}\text { Activity: } \\
\text { Confirm } \\
\text { land prep, } \\
\text { Inputs, } \\
\text { fertiliser and } \\
\text { weedicide } \\
\text { 3) Soil } \\
\text { sampling } \\
\text { results and } \\
\text { costing of } \\
\text { fertiliser \& } \\
\text { weedicides } \\
\text { Field } \\
\text { training day } \\
\text { Date: }\end{array}$ & $\begin{array}{l}\text { 4) Planting } \\
\text { training day } \\
\text { Date: }\end{array}$ & $\begin{array}{l}\text { 5) Weedicide } \\
\text { application } \\
\text { training day } \\
\text { Date: }\end{array}$ & $\begin{array}{l}\text { 6) Top } \\
\text { Dressing } \\
\text { training day } \\
\text { Date: }\end{array}$ \\
\hline PLANT & $\begin{array}{l}\text { Activity: } \\
\text { Check } \\
\text { weeds \& } \\
\text { address } \\
\text { issues }\end{array}$ & $\begin{array}{l}\text { 7) Pest, } \\
\text { Disease and } \\
\text { Variety } \\
\text { introduction } \\
\text { training day } \\
\text { Date: }\end{array}$ & $\begin{array}{l}\text { Activity: } \\
\text { List of growers } \\
\text { to buy } \\
\text { seedcane } \\
\text { 8) Harvesting } \\
\text { and cane } \\
\text { quality training } \\
\text { day } \\
\text { Date: }\end{array}$ & $\begin{array}{l}\text { 9) Role } \\
\text { Players } \\
\text { field day } \\
\text { Date: }\end{array}$ & $\begin{array}{l}\text { 10) Cane } \\
\text { payment } \\
\text { training day } \\
\text { Date: }\end{array}$ & $\begin{array}{l}\text { 11) } \\
\text { Estimating } \\
\text { training day } \\
\text { to confirm } \\
\text { yield } \\
\text { Date: }\end{array}$ & $\begin{array}{l}\text { 12) Field day } \\
\text { for seedcane } \\
\text { distribution } \\
\text { and establish } \\
\text { price } \\
\text { Date: }\end{array}$ & & & $\begin{array}{l}\text { Activity: } \\
\text { Distributing } \\
\text { seedcane }\end{array}$ & $\begin{array}{l}\text { Activity: } \\
\text { Inform } \\
\text { Stakeholders } \\
\text { following year }\end{array}$ & $\begin{array}{l}\text { Activity: } \\
\text { Plan for the } \\
\text { following } \\
\text { year }\end{array}$ \\
\hline
\end{tabular}

\section{Gillespie \& Mitchell}

(License: CC BY 4.0) 


\section{REFERENCES}

ALEX, G., ZIJP, W. \& BYERLEE, D., 2002. Rural extension and advisory services: New directions. Rural Strategy Background Paper No. 9. World Bank. Washington D.C., United States of America.

COCKBURN, J.J., COETZEE, H.C., VAN DER BERG, J., CONLONG, D.E. \& WITTHÖFT, J., 2014. Exploring the role of sugarcane in small-scale farmer's livelihoods in the Noodsberg area, KwaZulu-Natal, South Africa. S. Afr. J. Agric. Ext., 42(1):80-97.

GILLESPIE, W.A. \& MITCHELL, F.J., 2006. A successful methodology for the establishment of an extension programme in a small grower area. Proc. S. Afr. Sug. Technol. Ass., 80:188-189.

GILLESPIE, W.A. \& MITCHELL, F.J., 2014. Manual for the successful implementation of small-scale grower projects. SASRI. Mount Edgecombe, South Africa.

GILLESPIE, W.A. \& MITCHELL, F.J., 2015. Transforming communities through agriculture: Demonstration plot seedcane model improves the livelihoods of small-scale sugarcane growers. In Proceedings of the $19^{\text {th }}$ Congress of the International Farm Management Conference, Vol. 1, pp.123-129.

GILLESPIE, W.A., MITCHELL, F.J., WAY, M. \& WEBSTER, T., 2009. Demonstration plots double as seedcane nurseries for small-scale growers in the Noodsberg area. Proc. S. Afr. Sug. Technol. Ass., 82:623-635.

GILLESPIE, W.A., MITCHELL, F.J., WAY, M., WEBSTER, T. \& WITTHŐFT, J.H., 2012. Impact of new extension methodology on the performance of small growers. Proc. S. Afr. Sug. Technol. Ass., 85:205.

VAN NIEKERK, J.A., STROEBEL, A., VAN ROOYEN, C.J., WHITFIELD, K.P. \& SWANEPOEL, F.J.C., 2009. Towards designing a new agricultural extension service for the Eastern Cape Province: A perception analysis. S. Afr. J. Agric. Ext., 38(1):65-76.

VAN ROOYEN, C.J. \& BEMBRIDGE, T.J., 1998. Challenges for restructuring of small farmer support services. In: Agricultural policy reform for South Africa. African Institute for Policy Analysis and Economic Integration. 
